\title{
The system for adaptive control of axial tool oscillations in vibratory drilling: description and experimental study
}

llya Ivanov ( $D$ ivanovilig@gmail.com )

Bauman Moscow State Technical University: Moskovskij gosudarstvennyj tehniceskij universitet imeni N E Baumana nacional'nyj issledovatel'skij universitet https://orcid.org/0000-0003-2697-6354

\section{Sergey A. Voronov}

Bauman Moscow State Technical University: Moskovskij gosudarstvennyj tehniceskij universitet imeni N E Baumana nacional'nyj issledovatel'skij universitet Igor A. Kiselev

Bauman Moscow State Technical University: Moskovskij gosudarstvennyj tehniceskij universitet imeni N E Baumana nacional'nyj issledovatel'skij universitet

\section{Research Article}

Keywords: chip segmentation, vibration drilling head, adaptive control, control of vibrations, regenerative effect

Posted Date: February 24th, 2021

DOl: https://doi.org/10.21203/rs.3.rs-217088/v1

License: (9) This work is licensed under a Creative Commons Attribution 4.0 International License. Read Full License 


\section{Abstract}

Reliable segmentation and evacuation of chips from the cutting zone are essential for effective deep hole drilling. Drilling with low-frequency axial vibrations ensures these useful effects because cutting edges periodically leave the cutting zone. Useful tool vibrations can be maintained by using a special selfvibratory drilling head. The drilling head has an elastic element and ensures the self-excitation of vibrations due to the regenerative effect. However, high damping in the cutting zone suppresses axial selfvibrations and renders such a drilling head inexpedient for the industry. In this study, a novel system of adaptive control of the vibration drilling process was developed. The control objective is to maintain a specified peak-to-peak (PTP) value of vibration displacements. Due to in-process adaptation of the feedback gain, the control system supplies additional energy if vibrations are not self-excited and removes energy if the PTP vibration displacements are greater than the specified value. To test the workability of the system, an experimental setup was made. In the setup, the actuator force acts on an elastically fixed workpiece. The dynamic properties of the setup are equivalent to those of the vibration drilling head. The algorithm of feedback gain adaptation was implemented with a microcontroller. A number of experiments for different drilling regimes revealed that the control system successfully maintains the specified PTP value of displacements. The developed control system can be implemented on a vibration drilling head because only an accelerometer is required for control and the required actuator force is under $100 \mathrm{~N}$.

\section{Full Text}

Due to technical limitations, full-text HTML conversion of this manuscript could not be completed. However, the latest manuscript can be downloaded and accessed as a PDF.

\section{Figures}

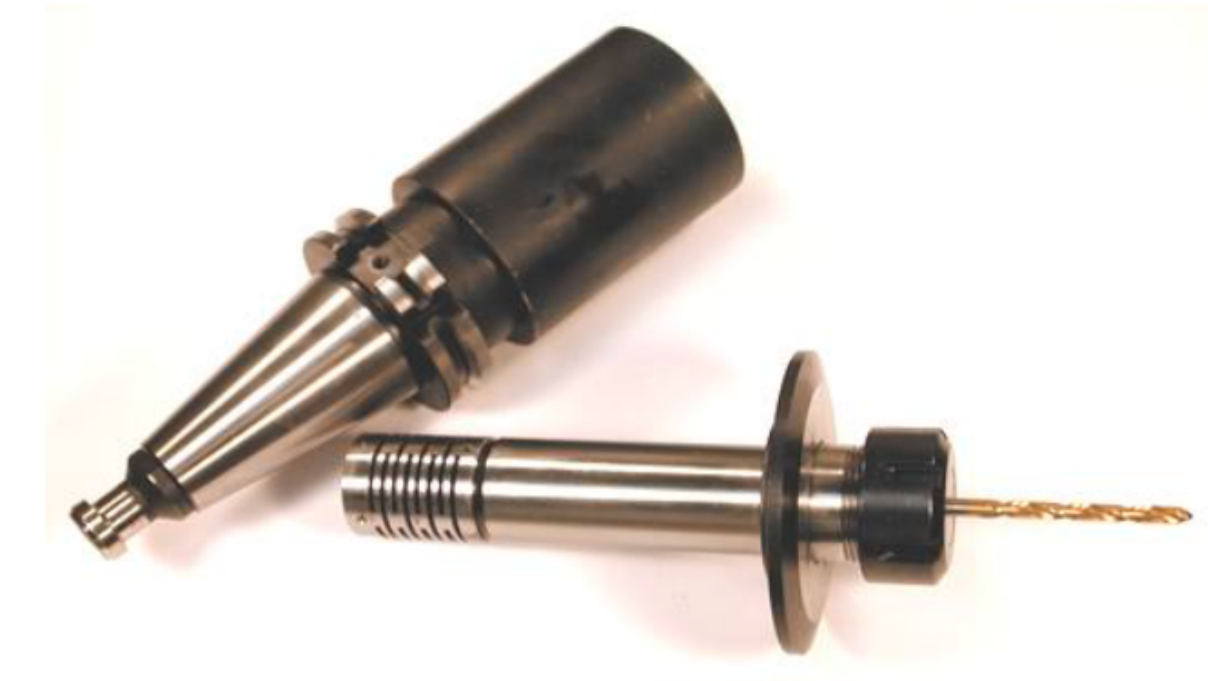

a)

b)

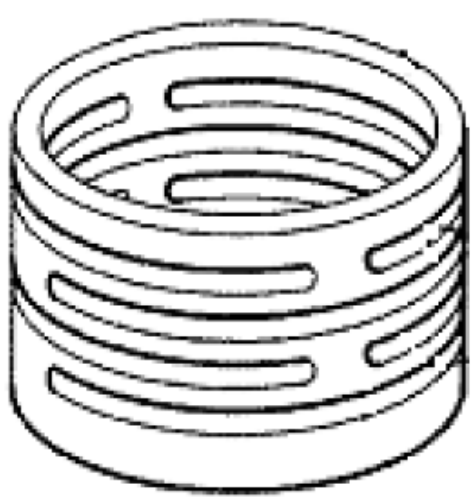


Figure 1

Photograph of a self-vibratory drilling head [7] with an integrated elastic element (a), an elastic element with openings (b) [8]

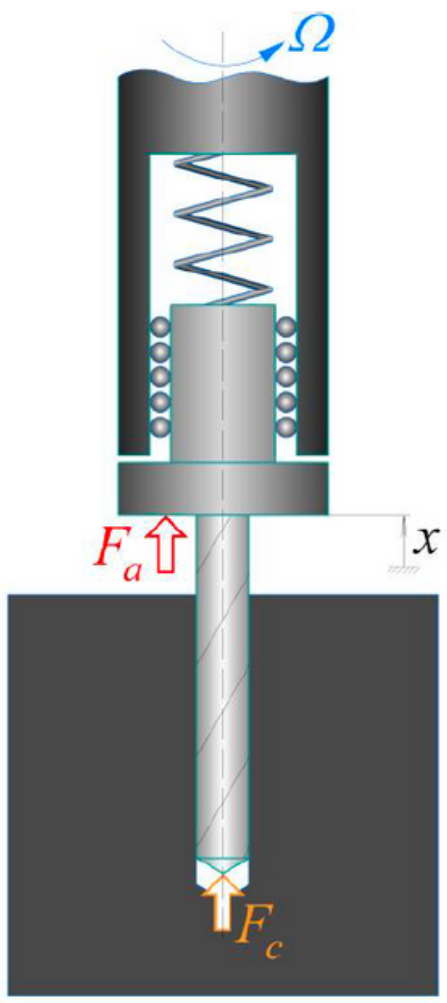

$F_{a}$ - control force, $F_{c}$ - axial cutting force, $x$ - coordinate of the moving part of VDH, $\Omega$ - spindle speed

Figure 2

Scheme of vibration drilling with control 


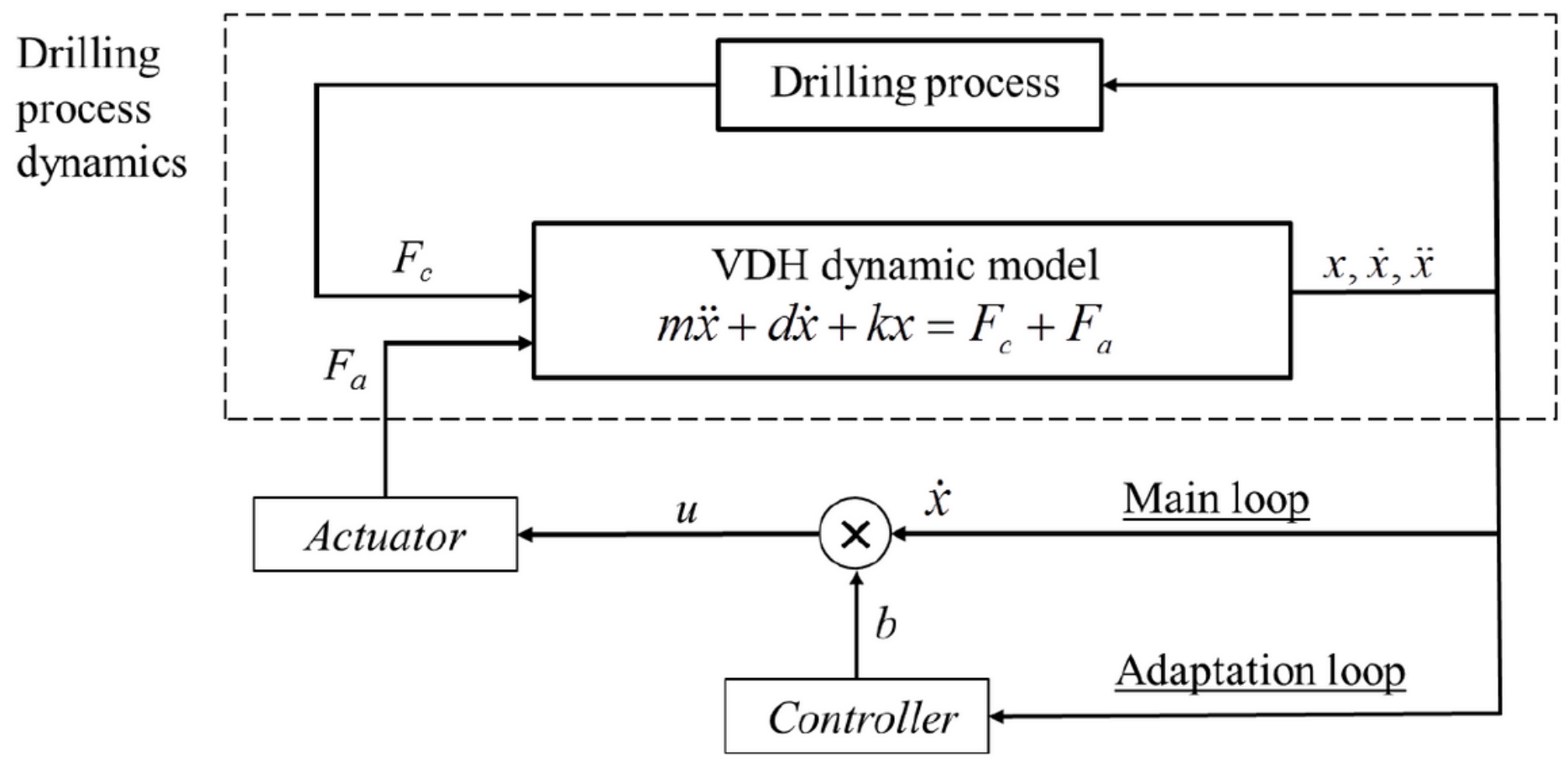

Figure 3

Block diagram of the closed-loop system «cutting - VDH - control system»
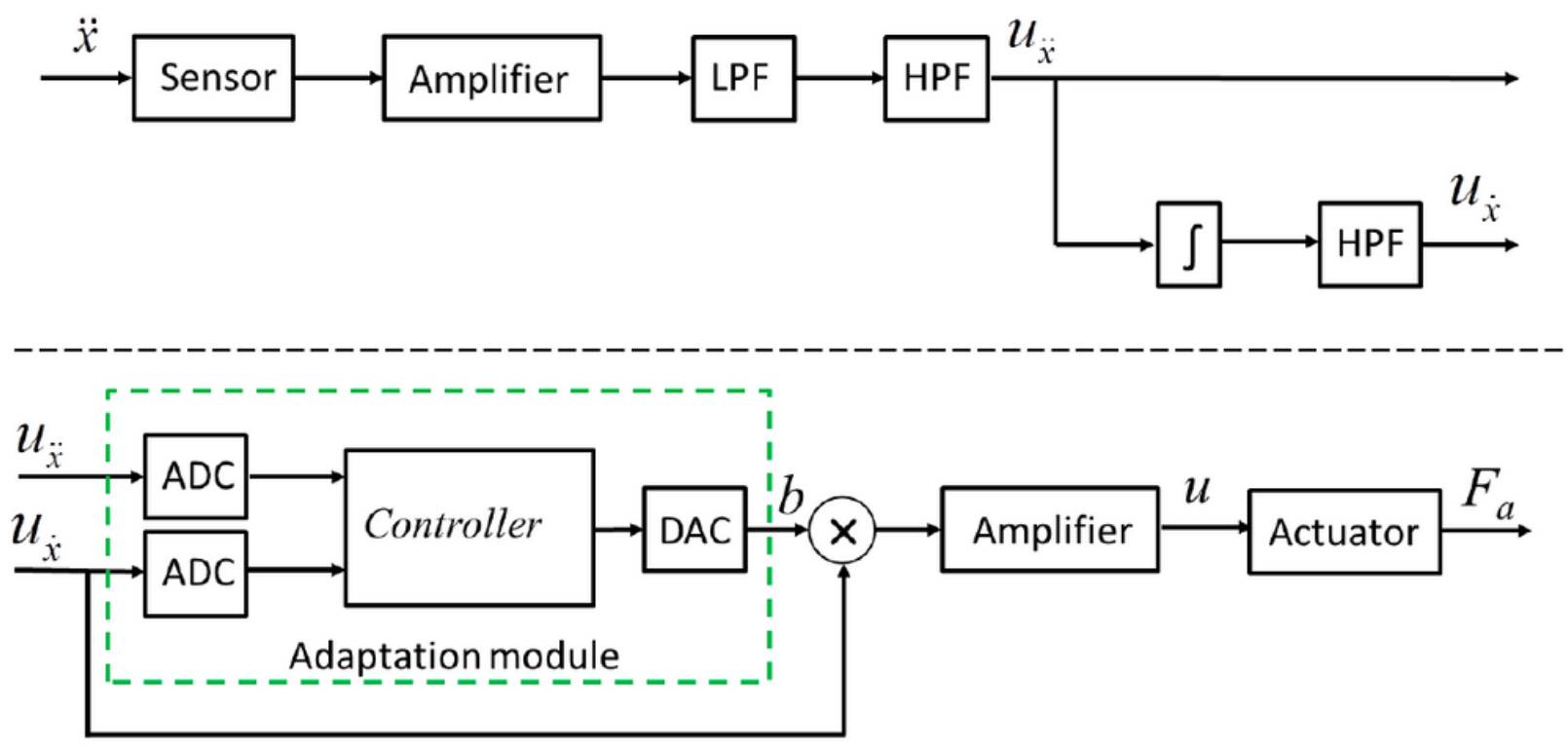

LPF - low-pass filter, HPF - high-pass filter, $u_{\dot{x}}$ - vibration acceleration signal, $u_{\dot{x}}$ - vibration velocity signal, ADC - analog-to-digital converter, DAC - digital-to-analog converter

Figure 4

Diagram of the hardware part of the control system 


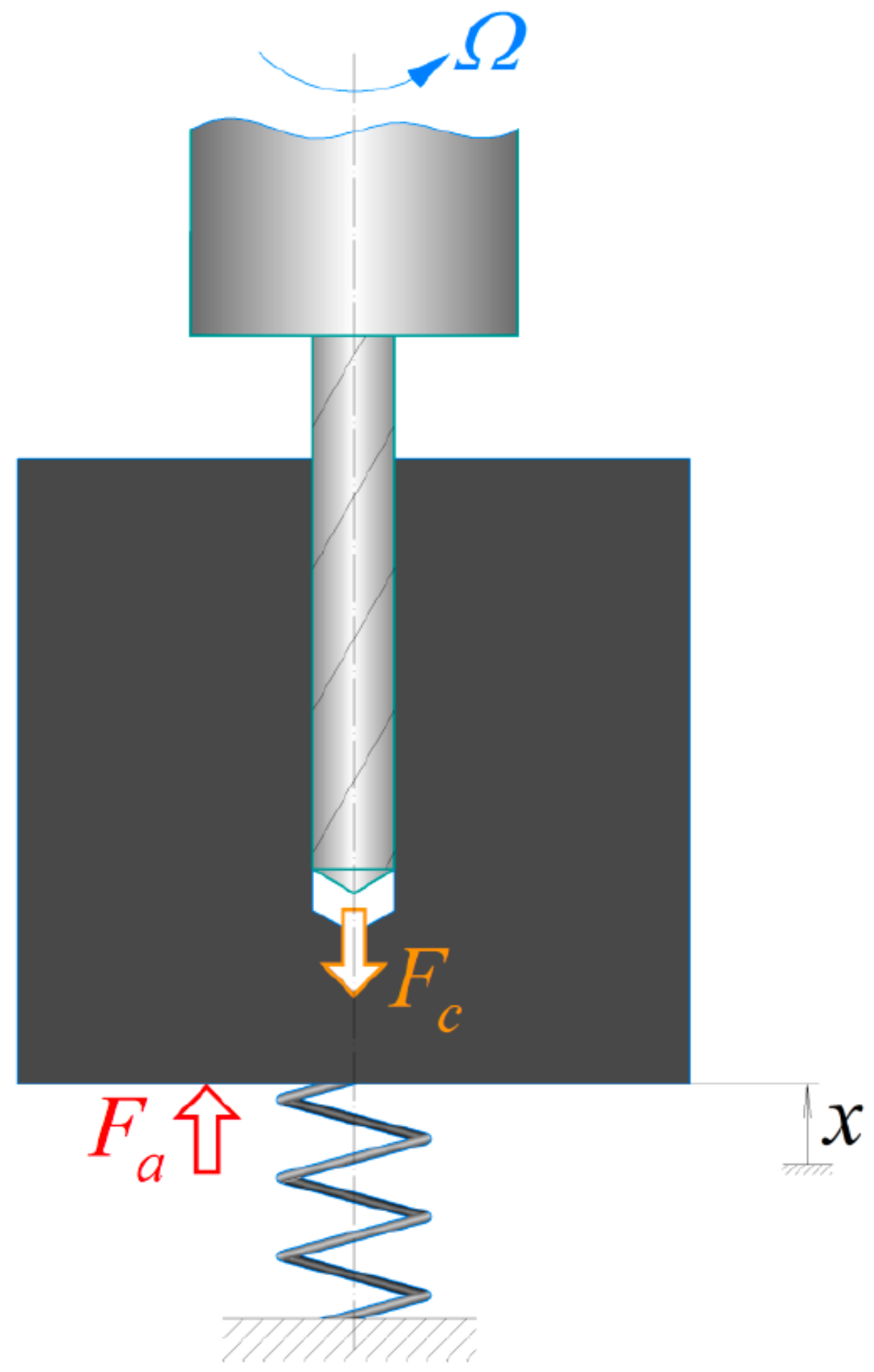

Figure 5

Scheme of the experimental setup 


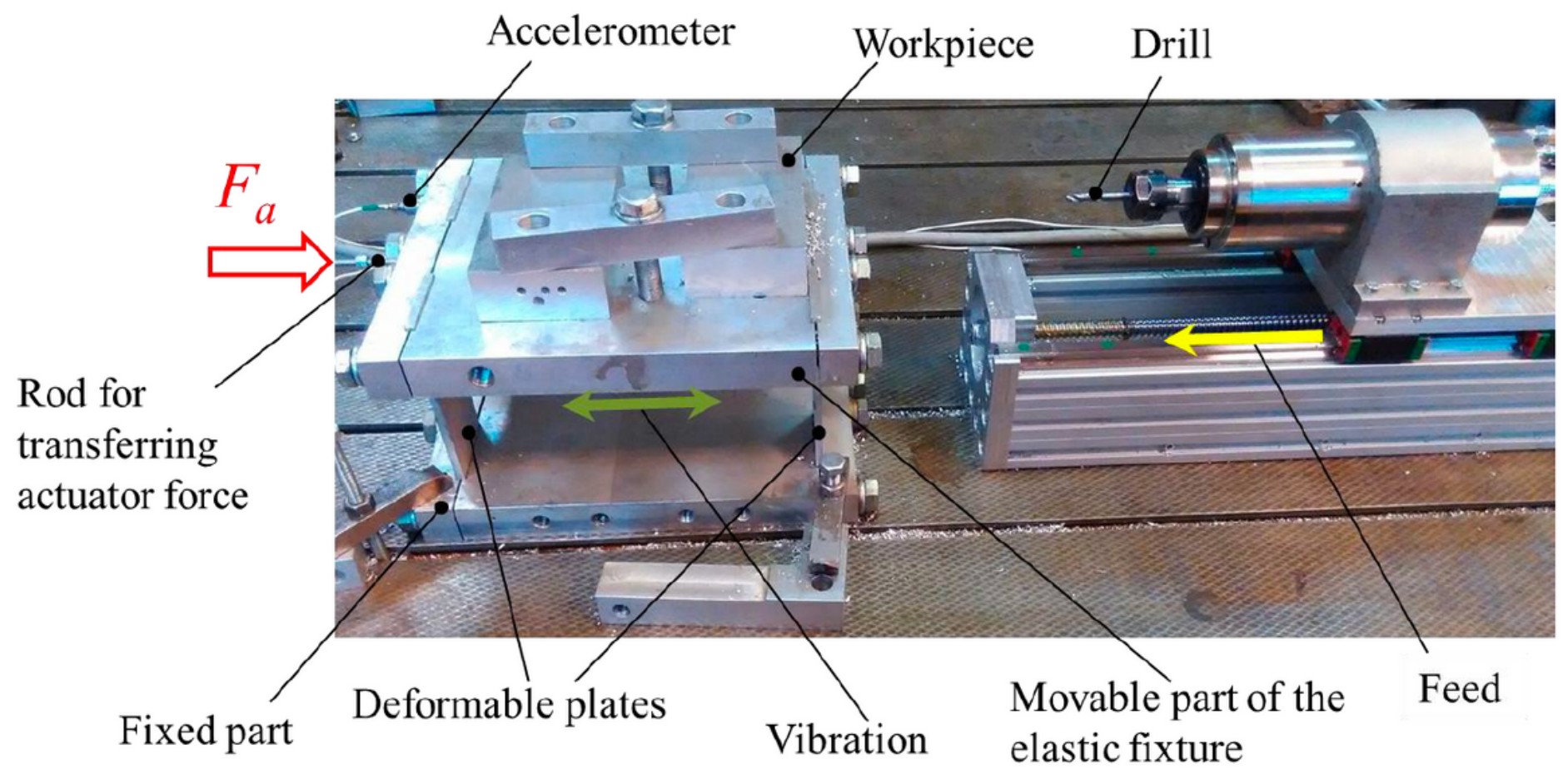

a) Vibration drilling setup

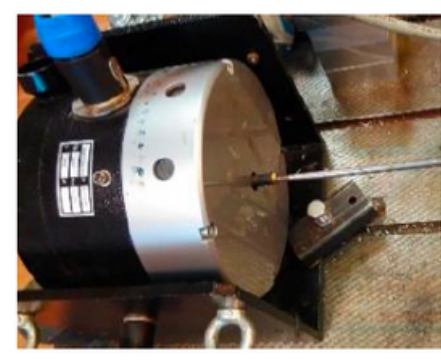

b) Actuator

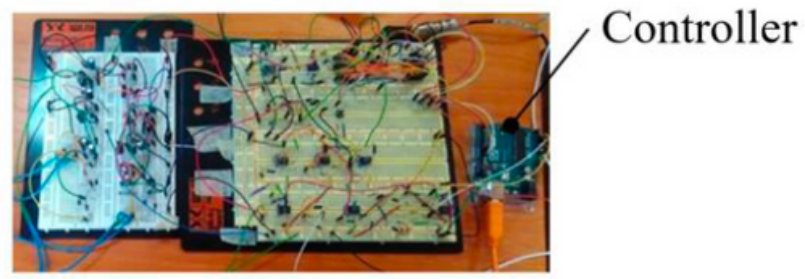

c) Control system

Figure 6

Experimental setup for vibration drilling with control 


\section{$\mathbf{d}=\mathbf{6} \mathbf{~ m m}$}

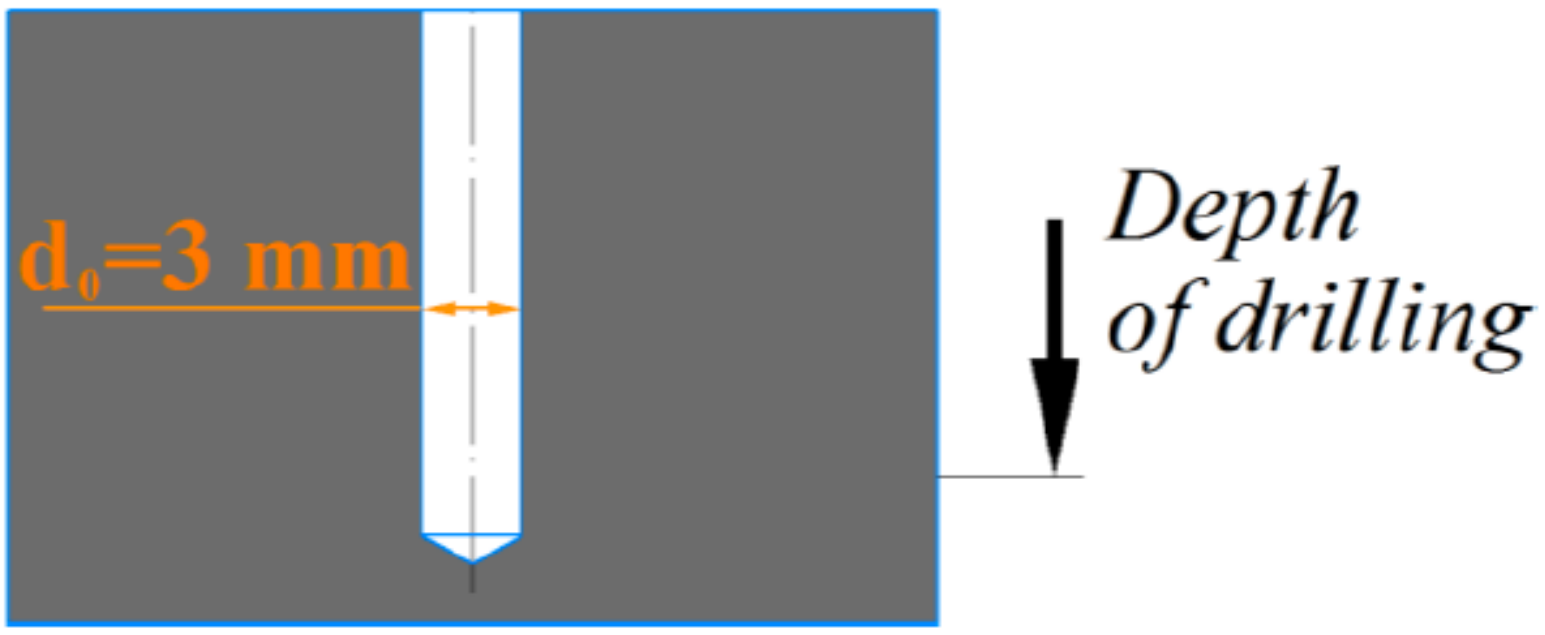

Figure 7

Drilling with a pilot hole
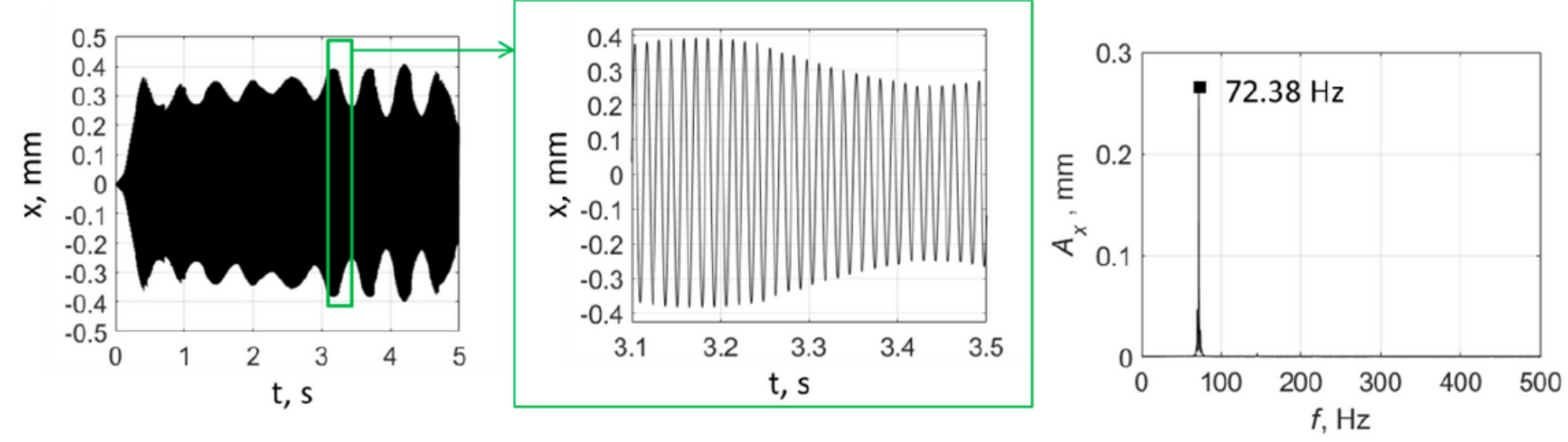

a) vibration displacements

b) vibration displacements (enlarged)

c) spectrum

Figure 8

Vibrations for drilling with a pilot hole without control, spindle speed $2500 \mathrm{rpm}$ 

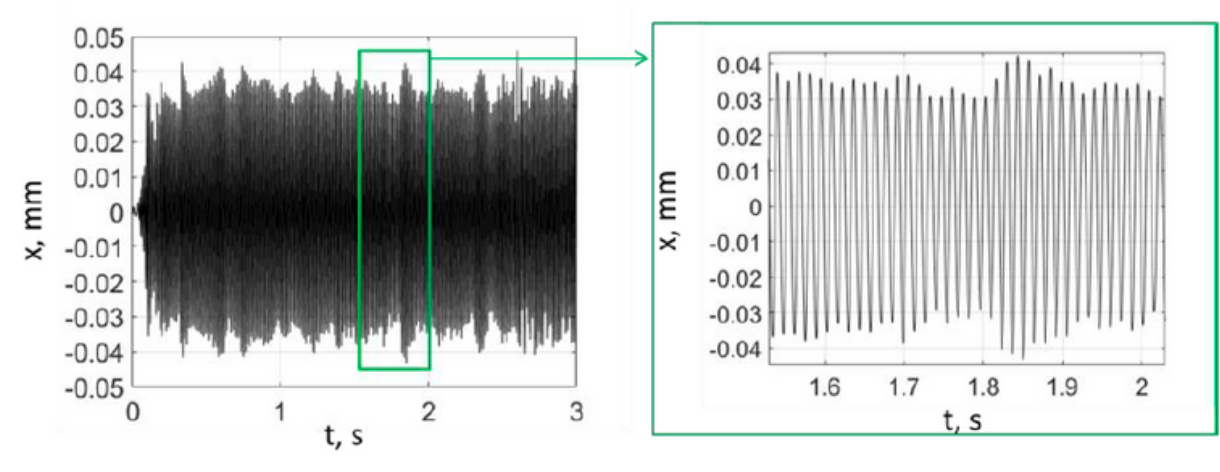

a) vibration displacements b) vibration displacements (enlarged)

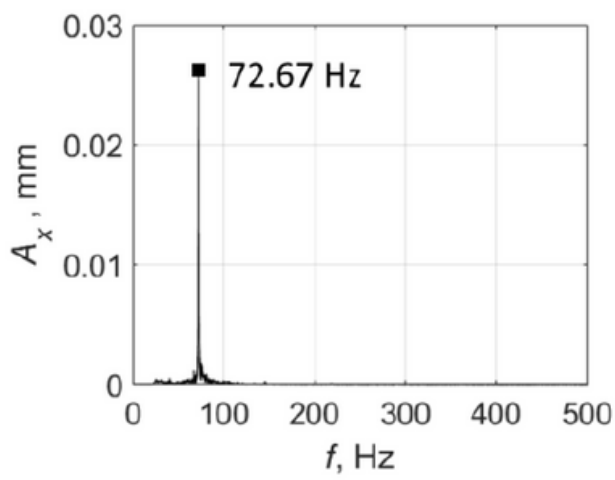

c) spectrum

\section{Figure 9}

Vibrations for drilling with a pilot hole with control, spindle speed $2500 \mathrm{rpm}$ 
Without control

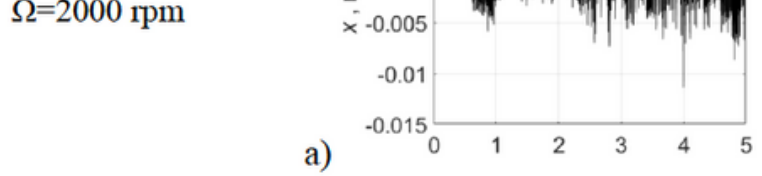

c)

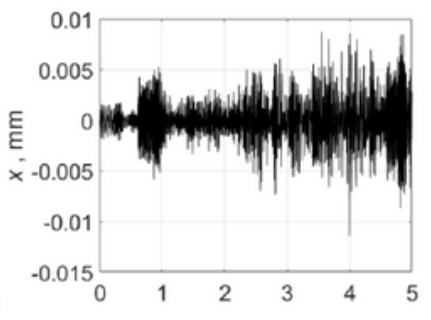

$\Omega=3000 \mathrm{rpm}$

$\Omega=3500 \mathrm{rpm}$

$\Omega=4000 \mathrm{rpm}$

$\Omega=4500 \mathrm{rpm}$

g)

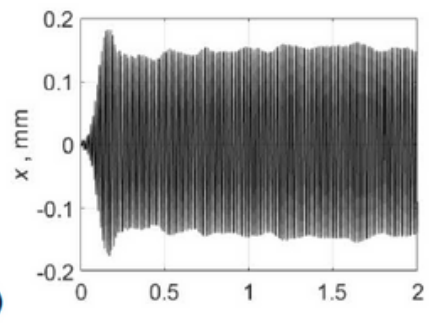

e)
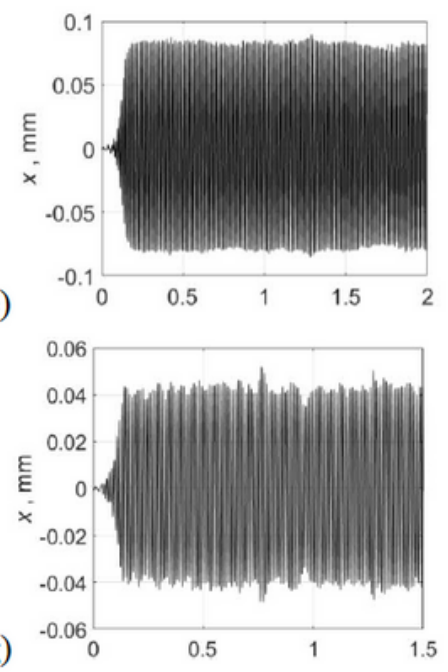

j)

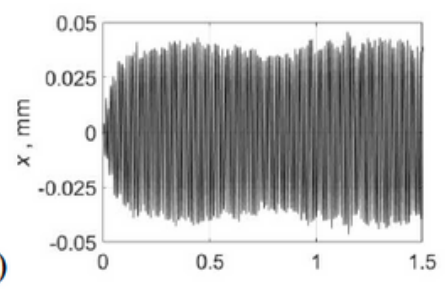

$\Omega=5000 \mathrm{rpm}$

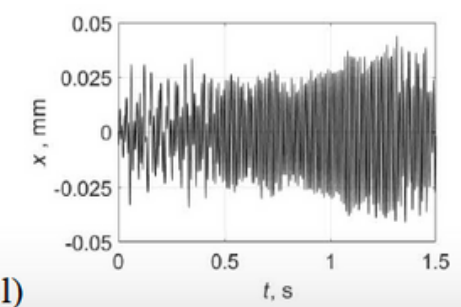

With control

b)

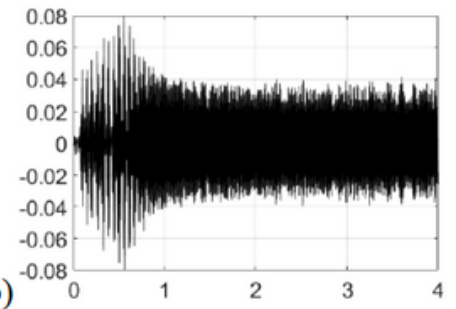

d)

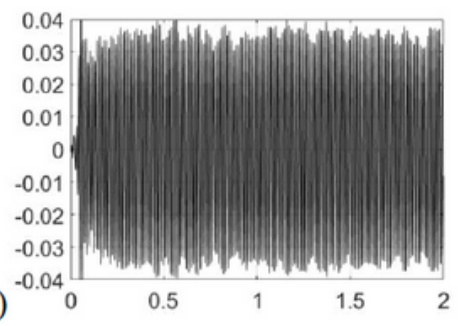

f)

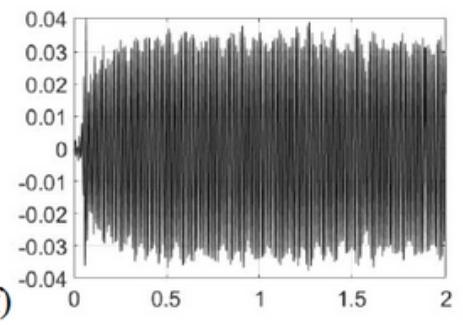

h)

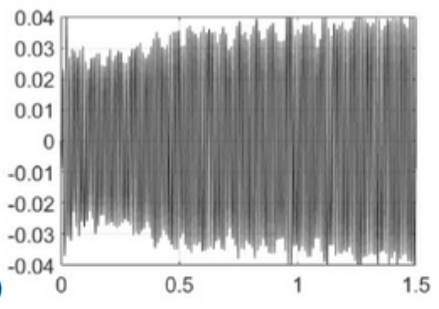

k)
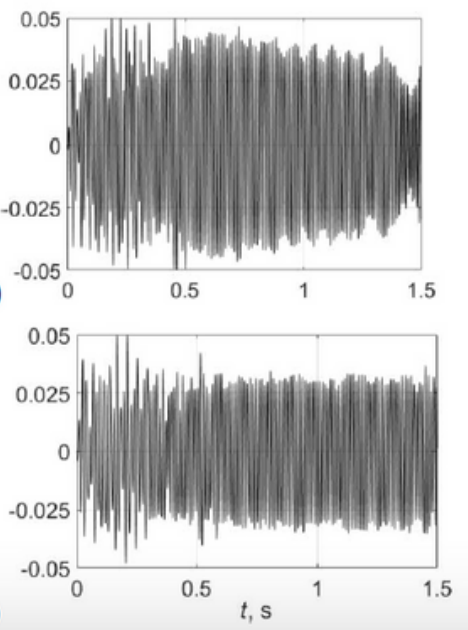

\section{Figure 10}

Time histories of vibration displacements for drilling with a pilot hole 


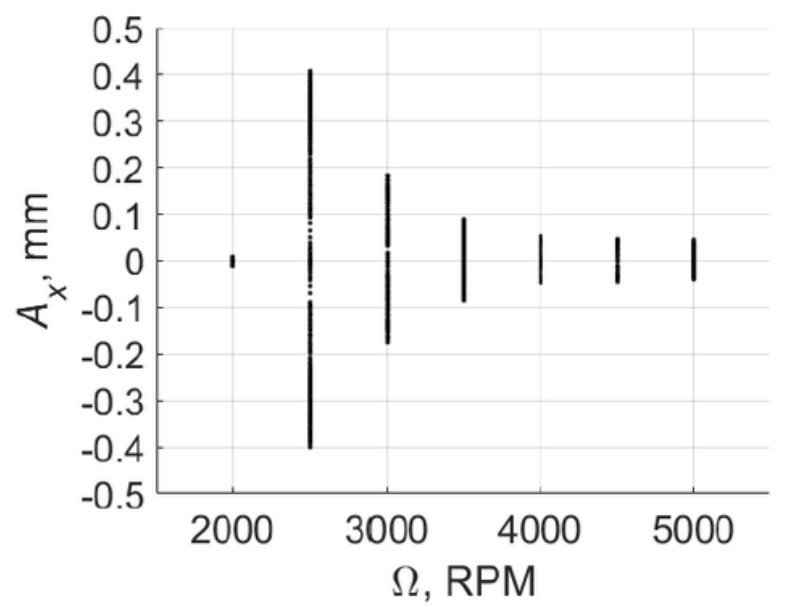

a) control off

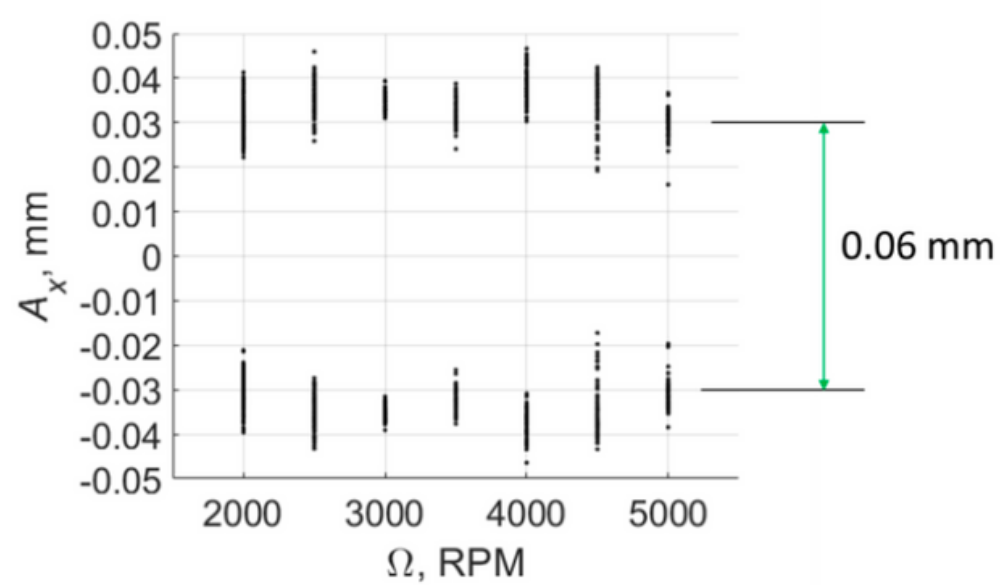

b) control on

Figure 11

Poincare maps of vibration displacements, drilling with a pilot hole

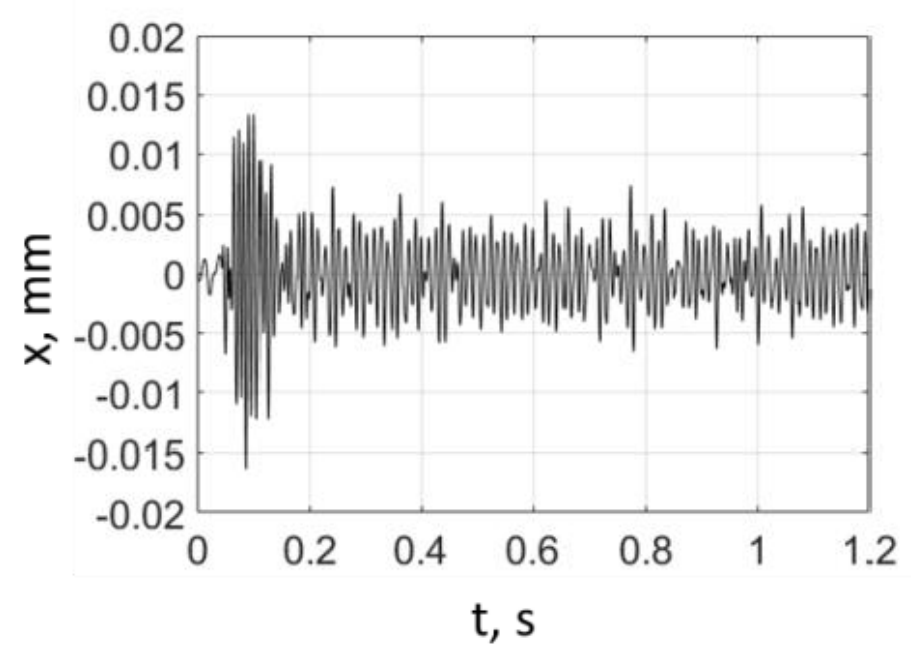

a) Vibration displacements

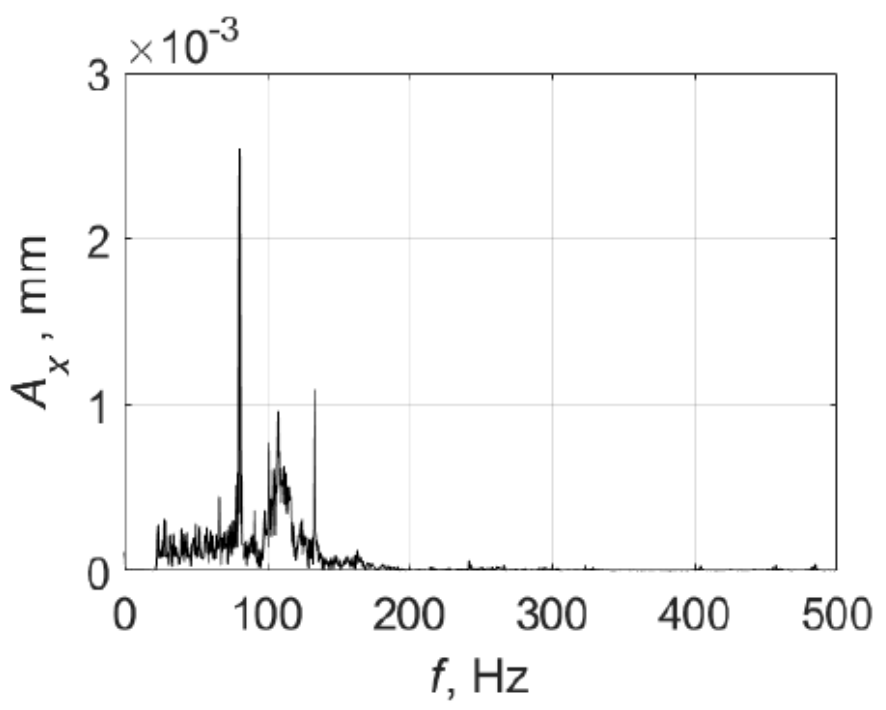

b) spectrum

Figure 12

Vibrations for full hole drilling without control, spindle speed $5000 \mathrm{rpm}$ 


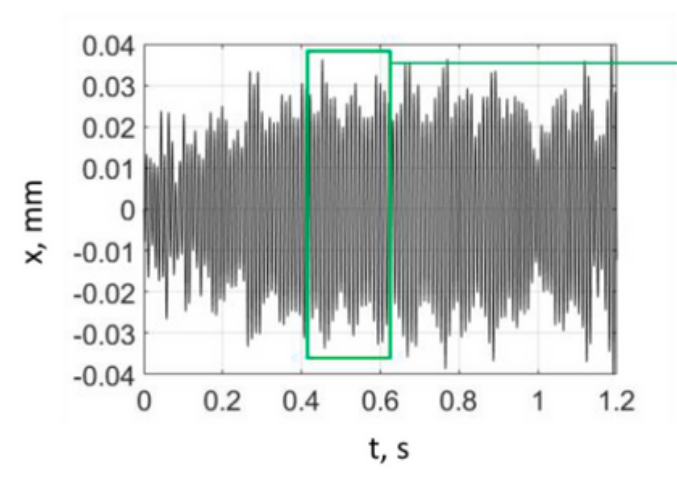

a) vibrations

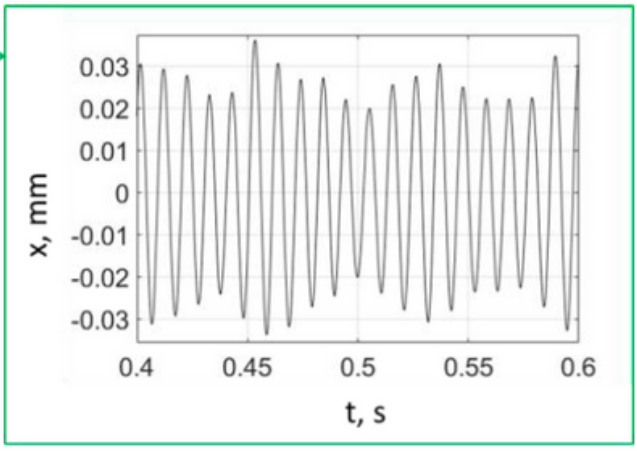

b) vibrations (enlarged)

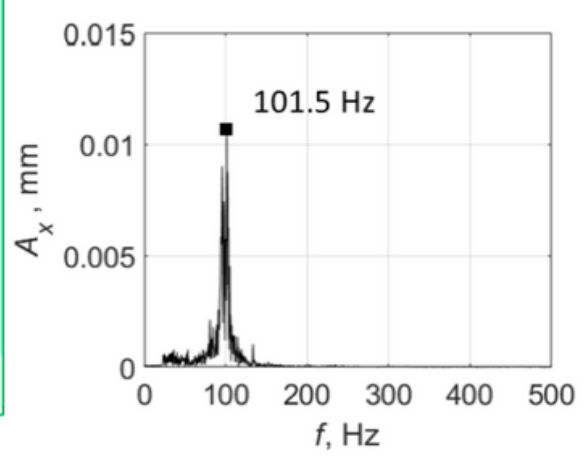

c) spectrum

Figure 13

Vibrations for full hole drilling with control, spindle speed $5000 \mathrm{rpm}$ 


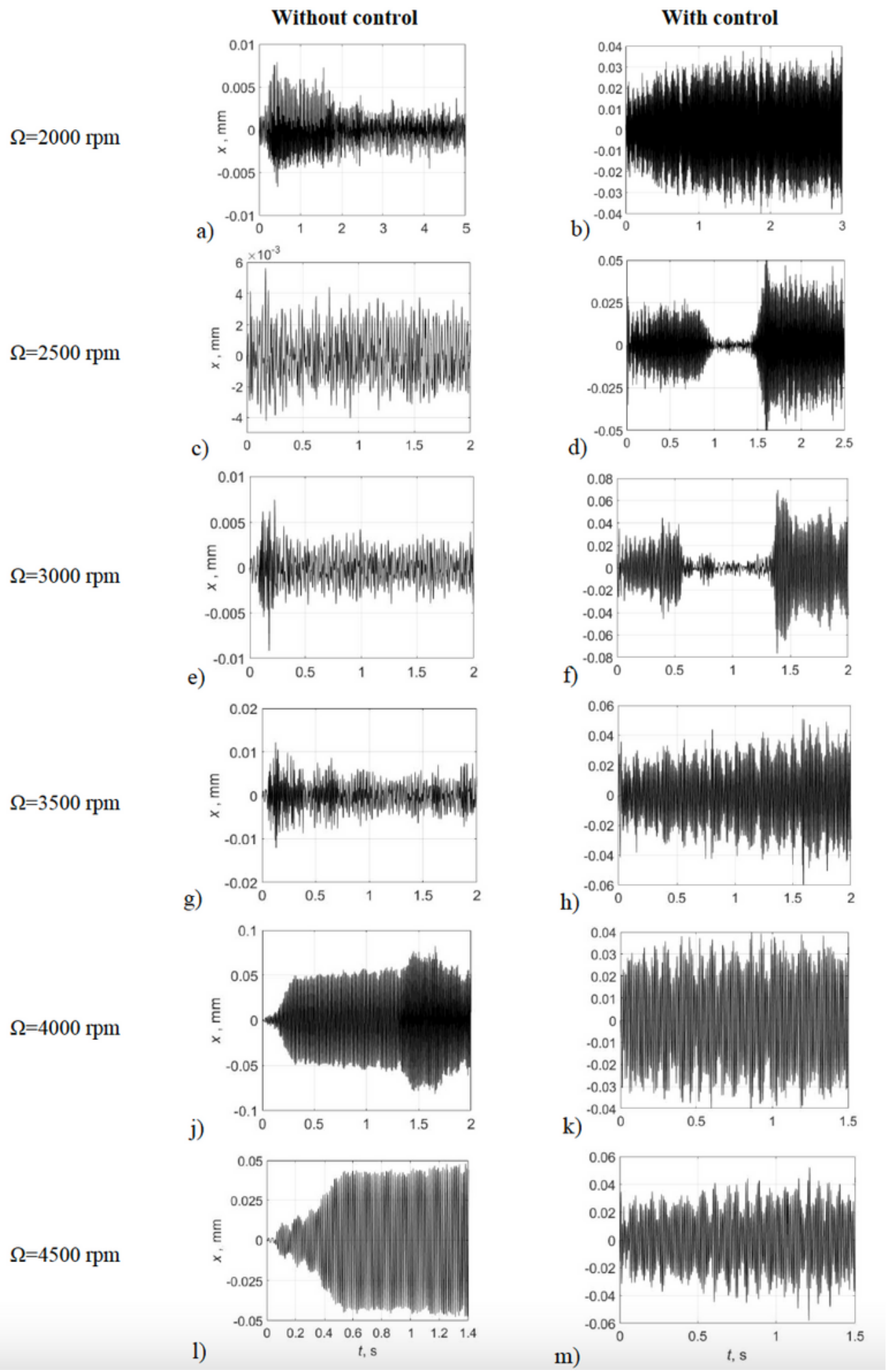

\section{Figure 14}

Time histories of vibration displacements for full hole drilling 


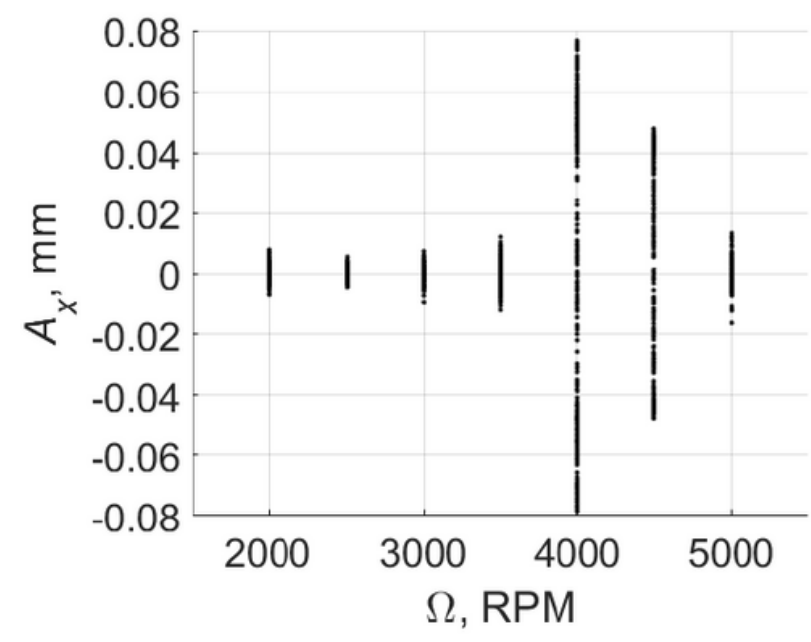

a) without control

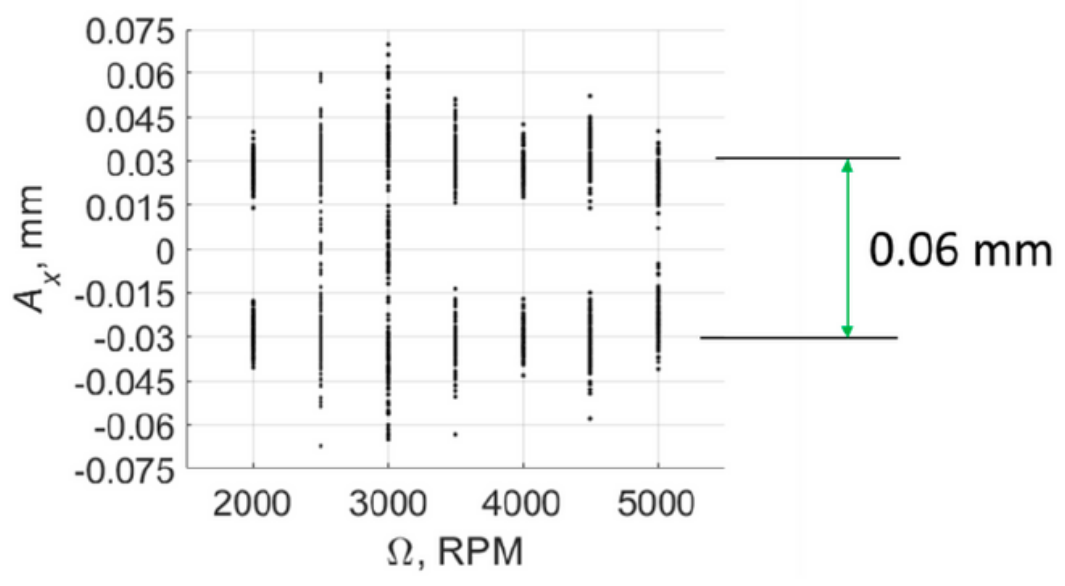

b) with control

Figure 15

Poincare maps of vibration displacements, full hole drilling

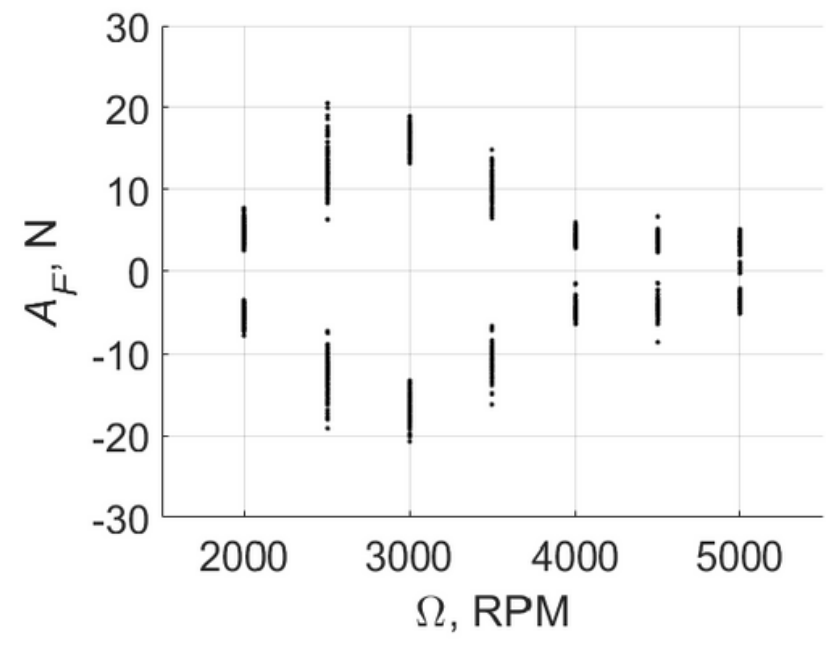

a) full hole drilling

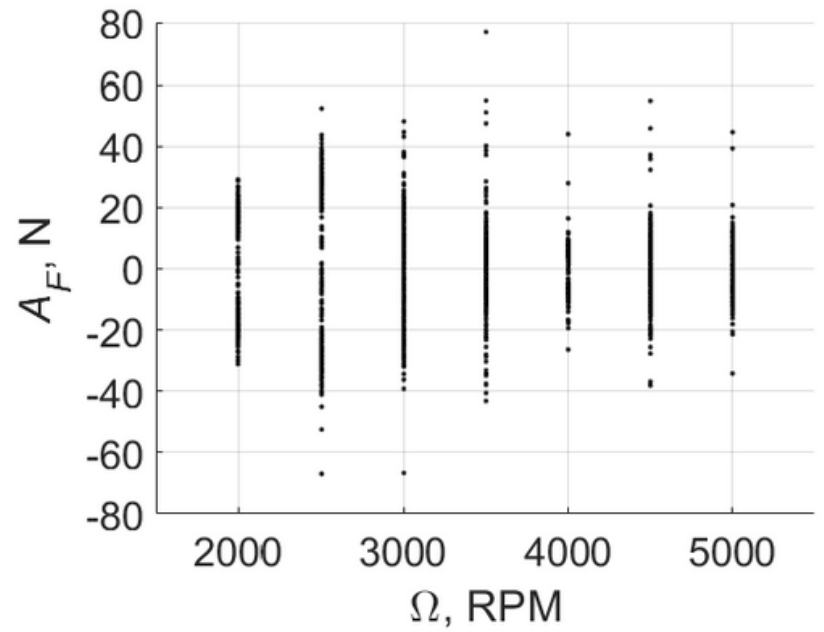

b) drilling with a pilot hole

Figure 16

Poincare maps of the actuator force, control is on.

\section{Supplementary Files}

This is a list of supplementary files associated with this preprint. Click to download.

- ControlOff.mp4

- ControlOn.mp4 